\title{
Enhanced G protein activation in IDDM patients with diabetic nephropathy
}

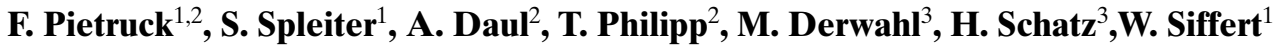 \\ ${ }^{1}$ Institut für Pharmakologie, Universitätsklinikum, Essen, Germany \\ ${ }^{2}$ Abteilung für Nieren- und Hochdruckkrankheiten, Zentrum für Innere Medizin, Universitätsklinikum, Essen, Germany \\ ${ }^{3}$ Medizinische Klinik, Berufsgenossenschaftliche Kliniken Bergmannsheil, Universitätsklinik, Bochum, Germany
}

Summary Genetic susceptibility contributes significantly to the risk of developing nephropathy in insulin-dependent diabetes mellitus (IDDM). The cellular substrate for this has remained enigmatic. We investigated whether afflicted IDDM patients display an enhanced activation of pertussis toxin (PTX)-sensitive $\mathrm{G}$ proteins, a phenomenon which has been demonstrated in patients with essential hypertension. We established immortalised B lymphoblast cell lines from 10 IDDM patients without nephropathy (DC) and 15 IDDM patients with nephropathy (DN). Nephropathy was defined as a persistent albumin excretion rate of more than $20 \mu \mathrm{g} / \mathrm{min}$ (DC $3.9 \pm 5.8$, DN $562.3 \pm 539.0 \mu \mathrm{g} / \mathrm{min}$, respectively). Subjects were matched with regard to age (DC $28.9 \pm 6.5$, DN $35.9 \pm 9.9$ years), diabetes duration (DC $19.3 \pm 6.9$, $\mathrm{DN} 22.7 \pm 5.8$ years) and $\mathrm{HbA}_{1 \mathrm{c}}$ values (DC $8.5 \pm 1.4$, DN $8.8 \pm 1.6 \%$ ). Reactivity of PTX-sensitive $\mathrm{G}$ proteins was quantified by measuring platelet-activating factor (PAF)-induced $\mathrm{Ca}^{2+}$ mobilisation (fura 2 method) and by mastoparan-stimulated $\left[{ }^{35} \mathrm{~S}\right] \mathrm{GTP} \gamma \mathrm{S}$ binding. Expression of $\mathrm{G} \alpha_{i}$ proteins was quantified by Western blot analysis. PAF-evoked $\mathrm{Ca}^{2+}$ increases above baseline averaged 77.0 \pm 52.5 $\mathrm{nmol} / \mathrm{l}$ in DC and $150.7 \pm 61.5 \mathrm{nmol} / 1$ in DN $(p=0.005)$. PAF-evoked $\mathrm{Ca}^{2+}$ increases correlated with stimulated $\left[{ }^{35} \mathrm{~S}\right] \mathrm{GTP} \gamma \mathrm{S}$ binding $\left(r^{2}=0.42\right.$, $p=0.012$ ). From Western blot analysis an overexpression of $G \alpha_{i}$ proteins could be excluded in DN. A consequence of the altered metabolic milieu in diabetes is the increased release of vasoactive and proliferative agonists which promote glomerular hyperfiltration, hypertrophy, enhanced matrix deposition, and, finally, glomerulosclerosis. Many of these auto- and paracrine agonists bind to $\mathrm{G}$ protein-coupled receptors. Therefore, their cellular effects are reinforced by the enhanced $G$ protein reactivity and increase the propensity to nephropathy in IDDM. [Diabetologia (1998) 41: 94--100]

Keywords Insulin-dependent diabetes mellitus, diabetic nephropathy, $\mathrm{G}$ protein activation, cellular signalling, lymphoblasts, platelet-activating factor.
Received: 9 May 1997 and in revised form: 3 September 1997

Corresponding author: Dr. F. Pietruck, Abteilung für Nierenund Hochdruckkrankheiten, Zentrum für Innere Medizin, Universitätsklinikum, Hufelandstrasse 55, D-45122 Essen, Germany

Abbreviations: DN, Patients with diabetic nephropathy; DC, patients without diabetic nephropathy; GTP $\gamma$ S, guanosine 5 '-[ $\gamma$-thio]-triphosphate; IDDM, insulin-dependent diabetes mellitus; MAS-7, Mastoparan 7; PAF, platelet-activating factor; PDGF, platelet-derived growth factor; PTX, pertussis toxin; FCS, fetal calf serum; TBS, tris-buffered saline; BSA, bovine serum albumin.
Diabetic nephropathy is now the leading cause of end-stage renal disease. About $37 \%$ of the incidence of end-stage renal failure is attributable to diabetes mellitus [1]. Approximately $40 \%$ of patients with insulin-dependent diabetes mellitus (IDDM) develop diabetic nephropathy (DN) during the course of their disease [2,3], microalbuminuria being highly predictive of subsequent overt nephropathy [4]. Besides poor glycaemic control, genetic susceptibility contributes significantly to the risk of diabetic renal disease as indicated by family studies on IDDM siblings of IDDM patients [5, 6]. Furthermore, hypertension and/or a parental history of cardiovascular disease 
Table 1. Characteristics of enrolled individuals

\begin{tabular}{lcc}
\hline & Diabetic patients without nephropathy & Diabetic patients with nephropathy \\
\hline$n$ (male/female) & $10(4 / 6)$ & $15(6 / 9)$ \\
Age (years) & $29 \pm 7(19--39)$ & $36 \pm 10(27--68)$ \\
Duration of IDDM (years) & $19 \pm 7(11--33)$ & $23 \pm 6(14--34)$ \\
$\mathrm{HbA}_{1 \mathrm{c}}(\%)$ & $8.5 \pm 1.4(6.9--10.3)$ & $8.8 \pm 1.6(6.0--11.7)$ \\
Serum creatinine $(\mu \mathrm{mol} / \mathrm{l})$ & $84 \pm 12(71--109)$ & $134 \pm 85(80--398)^{\mathrm{a}}$ \\
Creatinine-clearance $\left(\mathrm{ml} / \mathrm{min} \times 1.73 \mathrm{~m}^{2}\right)$ & $128 \pm 15(110--158)$ & $108 \pm 48(24--171)^{\mathrm{a}}$ \\
Albumin excretion $(\mu \mathrm{g} / \mathrm{min})$ & $4 \pm 6(0--15)$ & $562 \pm 539(24--1399)^{\mathrm{a}, \mathrm{b}}$ \\
Systolic blood pressure $(\mathrm{mm} \mathrm{Hg})$ & $128 \pm 8(116--140)$ & $133 \pm 22(100--164)$ \\
Diastolic blood pressure $(\mathrm{mm} \mathrm{Hg})$ & $80 \pm 3(74--84)$ & $79 \pm 13(59--108)$ \\
Antihypertensive therapy $(n)$ & 0 & 8 \\
Body mass index & $23.1 \pm 2.3(18.4--26.4)$ & $22.8 \pm 2.9(18.4--30.3)$ \\
\hline
\end{tabular}

Means $\pm \mathrm{SD}$, ranges are given in parentheses;

${ }^{\mathrm{a}}$ exclusive of two patients on haemodialysis; ${ }^{\mathrm{b}} p<0.01$ vs patients without nephropathy

are established risk factors for $\mathrm{DN}[7,8]$. At the cellular level, an enhanced $\mathrm{Na}^{+} / \mathrm{Li}^{+}$countertransport in erythrocytes constitutes a genetic marker for $\mathrm{DN}$ [9--11]. This ion transport apparently represents a special mode of operation of the ubiquitously expressed $\mathrm{Na}^{+} / \mathrm{H}^{+}$exchanger [12]. Moreover, an increased activity of the $\mathrm{Na}^{+} / \mathrm{H}^{+}$exchanger has been observed in erythrocytes and cultured skin fibroblasts from IDDM patients with DN [13, 14]. Subsequent investigations have revealed, that the "enhanced $\mathrm{Na}^{+} / \mathrm{H}^{+}$exchanger phenotype" " is conserved in Epstein-Barr virus-immortalised lymphoblasts from patients with essential hypertension [15] as well as from IDDM patients with DN [16]. In hypertension, this enhanced $\mathrm{Na}^{+} / \mathrm{H}^{+}$exchanger activity appears to be ultimately caused by an increased activation of pertussis toxin (PTX)-sensitive G proteins which results in an enhanced cellular reactivity, e.g. increased agonist-stimulated rises in $\left[\mathrm{Ca}^{2+}\right]_{i}$ and increased inositol 1,4,5-trisphosphate formation, as well as an accelerated cell growth $[17,18]$. Because increased proliferation has already been shown in immortalised lymphoblasts [19] and skin fibroblasts [14] from IDDM patients with DN, we speculated that enhanced $\mathrm{G}$ protein activation could be a common denominator of enhanced cellular reactivity in both hypertension and DN. We have, therefore, established immortalised B lymphoblast cell lines from IDDM patients with (DN) and without diabetic nephropathy (DC). The results suggest, that patients with DN actually display an enhanced activation of PTX-sensitive $\mathrm{G}$ proteins. This finding may help to establish a novel hypothesis regarding the pathogenesis of $\mathrm{DN}$.

\section{Subjects, materials and methods}

Materials. RPMI 1640 cell culture medium, L-glutamine and penicillin/streptomycin solution were from Gibco-BRL (Eggenstein, Germany). Fetal calf serum (FCS) was from Vitromex (Vilshofen, Germany). Platelet-activating factor (PAF) and mastoparan-7 (MAS-7) were obtained from Calbiochem
(Bad Soden, Germany). Fura 2-AM was purchased from Molecular Probes (Eugene, Ore., USA). Guanine nucleotides were from Boehringer Mannheim (Mannheim, Germany). $\left[{ }^{35} \mathrm{~S}\right]$ Guanosine $5^{\prime}-\left[\gamma\right.$-thio]triphosphate $\left(\left[{ }^{35} \mathrm{~S}\right] \mathrm{GTP} \gamma \mathrm{S}, 1200--\right.$ $1400 \mathrm{Ci} / \mathrm{mmol}$ ) was purchased from New England Nuclear-DuPont (Dreieich, Germany). Pertussis toxin was from List Biological Laboratories (Campbell, Calif., USA). The anti$\mathrm{G \alpha}_{\mathrm{i} \text {,common }}$ antibody was obtained from Calbiochem and the peroxidase-conjugated goat-anti-rabbit antibody from Sigma (Deisenhofen, Germany).

Patient characteristics. The study groups consisted of 10 patients with IDDM without nephropathy (DC) and 15 IDDM patients with nephropathy (DN), duration of IDDM being at least 10 years. The nephropathy status of the patients was determined by a timed collection of urine (collection period either $2 \times 2 \mathrm{~h}$, or $24 \mathrm{~h}$ ) and measurement of the albumin concentration by immunonephelometry. Nephropathy was defined as a persistent urinary albumin excretion of more than $20 \mu \mathrm{g} / \mathrm{min}$ or $30 \mathrm{mg} / 24 \mathrm{~h}$. The urinary albumin excretion rate was measured at least two times for each patient. Estimates of the endogenous creatinine clearance were performed either as a $2 \times 2 \mathrm{~h}$ or a $24 \mathrm{~h}$ creatinine clearance. All subjects had repeated measurements of blood pressure after $10 \mathrm{~min}$ of rest and antihypertensive medication was recorded. A family history of diabetes, hypertension, myocardial infarction, other cardiovascular diseases, stroke and hyperlipoproteinaemia was taken.

Characteristics of the two study groups are summarised in Table 1. IDDM patients with and without DN did not differ significantly regarding age, duration of diabetes, gender, glycaemic control and body mass index. However, both groups differed with respect to the markers of renal disease. DN patients included six with microalbuminuria, seven with macroalbuminuria and two already on haemodialysis. Renal disease was also reflected by higher serum creatinine values in the DN group. In addition, hypertension was diagnosed more often in the DN group as reflected by antihypertensive treatment. Of $15 \mathrm{DN}$ patients 8 were on antihypertensive medication, wherereas none of the 10 DC patients was treated with antihypertensives. Mean systolic and diastolic blood pressures were similar in both groups, although the diastolic blood pressure values in some of the patients in the DN group exceeded normotensive values. Additionally, in the DN group a family history of cardiovascular disease was reported more often (data not presented).

Lymphoblast culture. Fifty $\mathrm{ml}$ of blood was obtained from each patient, lymphocytes were isolated on a Ficoll-Diatrizoate 
gradient (Ficoll Paque; Pharmacia, Freiburg, Germany) and immortalised as described [15]. Cells were routinely maintained in RPMI 1640 medium supplemented with $2 \mathrm{mmol} / \mathrm{l}$ L-glutamine, $100 \mathrm{U} / \mathrm{ml}$ penicillin, $100 \mu \mathrm{g} / \mathrm{ml}$ streptomycin, and $10 \%$ FCS. Measurements of intracellular signal transduction were not started before the 12th--16th week after immortalisation. Repeated measurements were performed for agoniststimulated increases in $\left[\mathrm{Ca}^{2+}\right]_{\mathrm{i}}$ and GTP $\gamma \mathrm{S}$ binding with a minimum interval of 6 weeks between measurements to avoid fortuitous influences of the cell culture conditions.

$\mathrm{Ca}^{2+}$-measurements. Measurements of intracellular free calcium concentration $\left(\left[\mathrm{Ca}^{2+}\right]_{i}\right)$ were performed on cells seeded at $1 \times 10^{5}$ cells $/ \mathrm{ml}$ and cultured for $24 \mathrm{~h}$ in serum-free RPMI 1640 medium. Cells resuspended at $2 \times 10^{6}$ cells $/ \mathrm{ml}$ in serumfree medium were incubated with $3 \mu \mathrm{mol} / 1$ fura 2 -AM for $30 \mathrm{~min}$ at $37^{\circ} \mathrm{C}$. Thereafter, the cells were centrifuged and resuspended for an additional $30 \mathrm{~min}$ in RPMI 1640 medium containing $1 \mathrm{mmol} / \mathrm{C} \mathrm{Ca}^{2+}$ to allow for complete hydrolysis of the fluorescent dye. Before each single measurement, aliquots of cells $\left(0.5--1 \times 10^{6}\right.$ cells $)$ were transferred to Eppendorf tubes, briefly centrifuged and resuspended in $2 \mathrm{ml}$ pre-warmed HEPES buffer containing (in mmol/l): $135 \mathrm{NaCl}, 5 \mathrm{KCl}, 1$ $\mathrm{MgCl}, 1 \mathrm{CaCl}_{2}, 10$ Glucose, and $20 \mathrm{HEPES}, \mathrm{pH}$ 7.4. Measurements were performed using an LS 5B spectrofluorometer (Perkin Elmer Corp., Norwalk, Conn., USA) equipped with a thermostated cuvette holder and a fast-filter application. Cells were excited alternately at $340 / 380 \mathrm{~nm}$, and emission was recorded every $0.1 \mathrm{~s}$ at $495 \mathrm{~nm}$. For experiments under $\mathrm{Ca}^{2+}$ free conditions, $5 \mathrm{mmol} / \mathrm{l}$ EGTA (final concentration) was added to the cell suspension $30 \mathrm{~s}$ before addition of agonist. $\left[\mathrm{Ca}^{2+}\right]_{\mathrm{i}}$ was calculated as described [20]. On the day of the experiment, cells from each individual cell line were measured 3 to 7 times for each condition, and these measurements were repeated two to three times for each cell line several weeks or even months apart.

$\left[{ }^{35} S\right] G T P \gamma S$ binding. Determination of $\left[{ }^{35} \mathrm{~S}\right] \mathrm{GTP} \gamma \mathrm{S}$ binding to permeabilised cells was performed as described [21]. Lymphoblasts were growth-arrested as described above. After centrifugation $(120 \times \mathrm{g})$, the cell pellet was resuspended at $1 \times 10^{7}$ cells $\mathrm{ml}$ in a buffer containing (in $\mathrm{mmol} / \mathrm{l}$ ) $150 \mathrm{NaCl}, 5 \mathrm{MgCl}_{2}, 1$ EDTA, and 50 triethanolamine-HCL, $\mathrm{pH}$ 7.4. Aliquots $\left(1 \times 10^{6}\right.$ cells $)$ were transferred to the reaction mixture consisting of the same buffer supplemented with $10 \mu \mathrm{mol} / \mathrm{l}$ digitonin, $100 \mu \mathrm{mol} / \mathrm{l}$ adenosine $5^{\prime}$ - $[\beta, \gamma$-imino $]$ triphosphate and $10 \mu \mathrm{mol} / 1$ guanosine diphosphate (GDP), and the cells were permeabilised for $15 \mathrm{~min}$ at $30^{\circ} \mathrm{C}$. Thereafter, $30 \mu \mathrm{mol} / 1 \mathrm{mas}-$ toparan-7 (MAS-7) was added. After $1 \mathrm{~min}$, the $\left[{ }^{35} \mathrm{~S}\right] \mathrm{GTP} \gamma \mathrm{S}$ binding reaction was started by addition of $10 \mathrm{nmol} / \mathrm{l}$ $\left[{ }^{35} \mathrm{~S}\right] \mathrm{GTP} \gamma \mathrm{S}(0.1 \mu \mathrm{Ci} /$ tube $)$. The reaction was stopped after $10 \mathrm{~min}$ by rapid filtration through nitrocellulose filters rinsed four times with $3 \mathrm{ml}$ of ice-cold washing buffer consisting of $5 \mathrm{mmol} / \mathrm{l} \mathrm{MgCl}_{2}$ and $50 \mathrm{mmol} / \mathrm{l} \mathrm{Tris-HCL}$ (pH 7.5) for separation of protein-bound and free radioactivity. The filters were counted in a liquid scintillation spectrometer. Non-specific binding was defined as that not competed for by $10 \mu \mathrm{mol} / \mathrm{l}$ unlabelled GTP $\gamma \mathrm{S}$. Experiments were performed on cell lines from five DC and nine DN patients because the method was too difficult to be performed on all cell lines simultaneously. This would have been necessary to obviate interassay variations.

Immunoblotting. Crude lymphoblast cell membranes were prepared by nitrogen cavitation as described [17]. Cells seeded at a density of $1 \times 10^{6}$ cells $/ \mathrm{ml}$ in serum-containing RPMI 1640 medium and grown for 1 day were harvested, washed twice in phosphate-buffered saline (PBS), resuspended in icecold lysis buffer (in mmol/l: 250 sucrose, $1.5 \mathrm{MgCl}_{2}, 1$ ATP, 3 benzamidine, 1 phenylmethylsulfonyl fluoride, $2 \mu \mathrm{g} / \mathrm{ml}$ soybean trypsin inhibitor, and 20 Tris $/ \mathrm{HCl}, \mathrm{pH} 7.5$ ), and homogenised by nitrogen cavitation (15 min at 50 bar). The cavitate was centrifuged at $2500 \times g$ for $10 \mathrm{~min}$, and a crude membrane fraction was obtained from the resulting supernatant by centrifugation at $100000 \times g$ for $20 \mathrm{~min}$. The resulting pellet was washed in a buffer consisting of (in mmol/l) 1 EDTA, 1 dithiothreitol, 3 benzamidine, 1 phenylmethylsulfonyl fluoride, $2 \mu \mathrm{g} /$ $\mathrm{ml}$ soybean trypsin inhibitor, and $20 \mathrm{Tris} / \mathrm{HCl}, \mathrm{pH} 7.5$, resuspended, and finally stored in the same buffer at $--70^{\circ} \mathrm{C}$.

Protein concentration was determined according to Bradford [22] with bovine IgG as standard. Membrane proteins $(25 \mu \mathrm{g})$ were heated for $5 \mathrm{~min}$ at $95^{\circ} \mathrm{C}$ in sample buffer containing $5 \%$ 2-mercaptoethanol. They were fractionated by SDS-PAGE electrophoresis according to Laemmli [23] with $10 \%$ acrylamide in the running gel and $5 \%$ acrylamide in the stacking gel. Proteins were electrotransferred to nitrocellulose using a Trans-Blot electrophoretic transfer cell (Biorad, München, Germany) at $100 \mathrm{~V}$ for $1 \mathrm{~h}$. Nitrocellulose filters were blocked for $1 \mathrm{~h}$ at room temperature in Tris-buffered saline (TBS: $10 \mathrm{mmol} / \mathrm{l}$ Tris- $\mathrm{HCl} \mathrm{pH}$ 8.0, $150 \mathrm{mmol} / \mathrm{l} \mathrm{NaCl}$ ) containing $5 \%$ bovine serum albumin (BSA) and $0.1 \%$ Tween 20. Thereafter, the filters were washed three times for $5 \mathrm{~min}$ each in TBS containing $0.05 \%$ Tween 20 (TBS/Tween 20) and subsequently incubated for $60 \mathrm{~min}$ at room temperature with the primary antibody (anti $\mathrm{G \alpha}_{\mathrm{i} \text {,common }}$ ) which was diluted 1:1000 with TBS containing $0.1 \%$ BSA (TBS/BSA). The filters were washed four times for $5 \mathrm{~min}$ each in TBS/Tween 20 and incubated for another hour at room temperature in the peroxidase-conjugated antibody which was diluted at 1:5000 with TBS/BSA. The filters were treated with enhanced chemoluminescent (ECL)-reagent (Amersham, Braunschweig, Germany) according to the manufacturer and immunoreactive bands were visualised by autoradiography.

Statistical analysis. All data are given as mean \pm SD if not indicated otherwise. Comparison between groups were made using Student's $t$-test or, if appropriate Mann-Whitney U test. Differences were regarded as significant at $p$ less than 0.05. All calculations were performed using the computer program StatView, version 4.0 for Macintosh, Abacus Concepts, Inc. (Berkeley, Calif., USA).

\section{Results}

$P A F$-stimulated increases in $\left[\mathrm{Ca}^{2+}\right]_{i}$. Mean values of basal $\left[\mathrm{Ca}^{2+}\right]_{\mathrm{i}}$ in the presence of $1 \mathrm{mmol} / 1$ external $\mathrm{Ca}^{2+}$ were not significantly different in lymphoblasts from both groups (DC: $84 \pm 27 \mathrm{nmol} / 1, n=83$ measurements; DN: $87 \pm 27 \mathrm{nmol} / \mathrm{l}, \quad n=165$ measurements). Addition of $0.1 \mu \mathrm{mol} / \mathrm{l} \mathrm{PAF}$ consistently induced a rapid, transient increase in $\left[\mathrm{Ca}^{2+}\right]_{i}$, which peaked within 15 to $30 \mathrm{~s}$ and then declined to a new steady state level above baseline (Fig. 1A, B). We observed differences in the increase in $\left[\mathrm{Ca}^{2+}\right]_{\mathrm{i}}$ above basal levels between lymphoblasts from $\mathrm{DN}$, and lymphoblasts from DC patients, which also resulted in different sizes of the areas under the curve (Fig. 1A, B). Figure 2A depicts the mean increases in $\left[\mathrm{Ca}^{2+}\right]_{\mathrm{i}}$ above basal values for different cell lines upon stimulation with $0.1 \mu \mathrm{mol} / 1 \mathrm{PAF}$ in the presence 

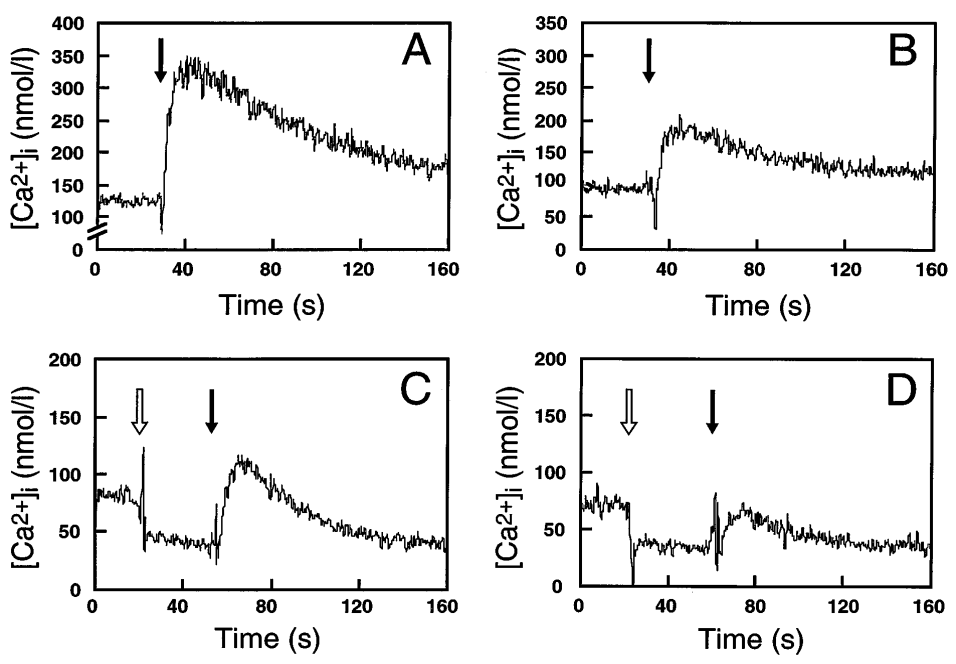

Fig. 1. Representative tracings of changes in cytosolic free $\mathrm{Ca}^{2+}$ concentrations $\left(\left[\mathrm{Ca}^{2+}\right]_{\mathrm{i}}\right)$ induced by platelet-activating factor (PAF) in human lymphoblast cell lines from two IDDM patients, one having developed diabetic nepropathy $(\mathbf{A}, \mathbf{C})$, the other without $(\mathbf{B}, \mathbf{D})$. Serum-deprived lymphoblasts loaded with fura 2-AM and incubated in HEPES buffer were exposed to $0.1 \mu \mathrm{mol} / 1 \mathrm{PAF}$ (solid arrows) in the presence of $1 \mathrm{mmol} / \mathrm{l}$ extracellular $\mathrm{Ca}^{2+}(\mathbf{A}, \mathbf{B})$, and after chelation of extracellular $\mathrm{Ca}^{2+}$ ions with $5 \mathrm{mmol} / \mathrm{l}$ EGTA (transparent arrows; $\mathbf{C}, \mathbf{D}$ )

of $1 \mathrm{mmol} / \mathrm{l}$ external $\mathrm{Ca}^{2+}$. In the $\mathrm{DC}$ group, $0.1 \mu \mathrm{mol} / \mathrm{l} \mathrm{PAF}$ induced a mean increase in $\left[\mathrm{Ca}^{2+}\right]_{\mathrm{i}}$ by $77.0 \pm 52.5 \mathrm{nmol} / \mathrm{l}$ above baseline $(n=10)$, whereas in the DN group the mean increase above baseline amounted to $150.7 \pm 61.5 \mathrm{nmol} / \mathrm{l}(n=15)$. This difference was statistically significant $(\mathrm{p}=0.005)$. A difference in the slope of the rise or decline in $\mathrm{Ca}^{2+}$ mobilisation between the two groups was not noted (Fig.1A, B).

Upon chelation of extracellular $\mathrm{Ca}^{2+}$ ions by addition of $5 \mathrm{mmol} / \mathrm{l}$ EGTA to the cell suspension, basal $\left[\mathrm{Ca}^{2+}\right]_{\mathrm{i}}$ values fell to $39 \pm 17 \mathrm{nmol} / \mathrm{l}(n=72)$ in DC and $41 \pm 15 \mathrm{nmol} / \mathrm{l}(n=126)$ in $\mathrm{DN}$ cell lines. The subsequent stimulation of the cells with $0.1 \mu \mathrm{mol} / 1$ PAF still induced an increase in $\left[\mathrm{Ca}^{2+}\right]_{\mathrm{i}}($ Fig. 1C, D), which ranged from $0--100 \mathrm{nmol} / \mathrm{l}$ in DC cell lines and from 30--140 nmol/l in DN cell lines (Fig. 2B). The mean increase in $\left[\mathrm{Ca}^{2+}\right]_{\mathrm{i}}$ of $38.0 \pm 25.7 \mathrm{nmol} / 1$ in the $\mathrm{DC}$ group and $70.0 \pm 29.0 \mathrm{nmol} / \mathrm{l}$ in $\mathrm{DN}$ was significantly different $(p=0.0097)$.

Subdivision of the DN group into patients with (DN-HT) or without (DN-NT) antihypertensive treatment revealed differences in the increase in $\left[\mathrm{Ca}^{2+}\right]_{\mathrm{i}}$, the values for the subgroups being $114.3 \pm 45.0 \mathrm{nmol} / \mathrm{l}$ for DN-NT $(n=7)$ and $182.5 \pm 57: 8 \mathrm{nmol} / 1$ for DN-HT $(n=8)$ in the presence of extracellular $\mathrm{Ca}^{2+}$ (Fig.2A); the $\Delta\left[\mathrm{Ca}^{2+}\right]_{\mathrm{i}}$ values in the absence of extracellular $\mathrm{Ca}^{2+}$ being $58.6 \pm 22.7 \mathrm{nmol} / 1$ and $80.0 \pm 31.6 \mathrm{nmol} / 1$, respectively

(Fig.2B). These differences reached statistical significance only in the presence of extracellular $\mathrm{Ca}^{2+}$ ( $p=0.026$ and $p=0.16$, respectively).

Correlation of MAS-7-stimulated $\left[{ }^{35} S\right] G T P \gamma S$ binding and $P A F$-evoked $\left[\mathrm{Ca}^{2+}\right]_{i}$ rises. To investigate whether the magnitude of the PAF-induced increases in $\left[\mathrm{Ca}^{2+}\right]_{\mathrm{i}}$ correlates with the activation of PTX-sensitive $G_{i}$ proteins, we determined the MAS-7-stimulated binding of $\left[{ }^{35} \mathrm{~S}\right] \mathrm{GTP} \gamma \mathrm{S}$ to permeabilised lymphoblasts from DC and DN. The peptide MAS-7 mimics the configuration of an activated $\mathrm{G}$ protein-coupled receptor and is, therefore, used as a direct activator of $\mathrm{G}$ proteins in the absence of receptor agonists [24]. The addition of MAS-7 $(30 \mu \mathrm{mol} / \mathrm{l})$ to permeabilised lymphoblasts stimulated $\left[{ }^{35} \mathrm{~S}\right] \mathrm{GTP} \gamma \mathrm{S}$ binding by $60-$ $276 \%$ above control in the 14 different B lymphoblast cell lines (5 DC and $9 \mathrm{DN}$ ) investigated. The mean stimulation above control was $122.8 \pm 86.1 \%$ for DC and $161.8 \pm 70.8 \%$ for DN. Although there was a tendency in DN to an enhanced stimulation of $\left[{ }^{35} \mathrm{~S}\right] \mathrm{GTP} \gamma \mathrm{S}$ binding compared to DC, this difference did not reach statistical significance $(p=0.38)$. Nevertheless, when the PAF-induced increases in $\left[\mathrm{Ca}^{2+}\right]_{\mathrm{i}}$ were plotted against MAS-7 stimulated binding of $\left[{ }^{35} \mathrm{~S}\right] \mathrm{GTP} \gamma \mathrm{S}$ (Fig. 2), linear regression analysis revealed a significant correlation between the direct activation of $\mathrm{G}_{\mathrm{i}}$ type $\mathrm{G}$ proteins by MAS-7 and the PAF-induced increases in $\left[\mathrm{Ca}^{2+}\right]_{\mathrm{i}}\left(r^{2}=0.42 ; p=0.012\right)$.

$G \alpha_{i}$ protein expression. To investigate whether enhanced $\mathrm{G}$ protein activation in B lymphoblasts from DN is caused by an overexpression of PTX-sensitive $\mathrm{G}$ proteins, the expression of $\mathrm{G} \alpha_{i}$ was quantified by Western blot analysis. Figure 3 displays a representative analysis of $\mathrm{G} \alpha_{\mathrm{i}}$-subunit expression as assessed using an anti-G $\alpha_{i, c o m m o n}$ antibody. This antibody detected a single band at about $42 \mathrm{kDa}$. Densitometric analysis demonstrated a similar density for DC $(46.71 \pm 8.89$ arbitrary units; $n=4)$ and $\mathrm{DN}$ $(50.12 \pm 17.98$ arbitrary units; $n=5)$. 

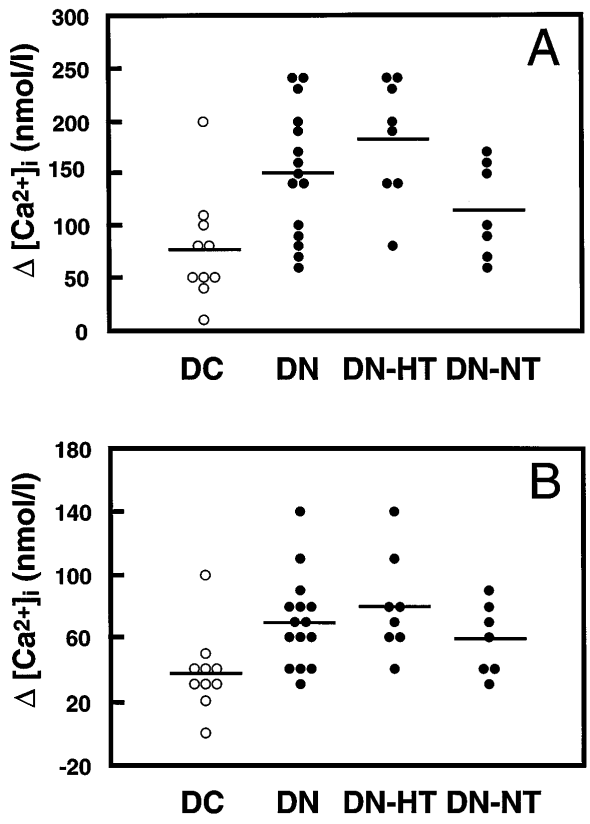

Fig. 2. Platelet-activating factor (PAF, $0.1 \mu \mathrm{mol} / \mathrm{l})$-induced rises in cytosolic free calcium concentration above baseline $(\triangle$ $\left[\mathrm{Ca}^{2+}\right]_{\mathrm{i}}$ ) in lymphoblasts from IDDM patients without (DC) and with (DN) diabetic nephropathy. The DN group was subdivided into patients who were treated with antihypertensives (DN-HT) or not (DN-NT); $\mathbf{A}$ in the presence of $1 \mathrm{mmol} / \mathrm{l} \mathrm{ex}-$ tracellular $\mathrm{Ca}^{2+}(p<0.01, \mathrm{DN}$ vs DC; $p<0.05, \mathrm{DN}-\mathrm{HT}$ vs DN-NT); $\mathbf{B}$ in the absence of extracellular $\mathrm{Ca}^{2+}$ after chelation with $5 \mathrm{mmol} / 1$ EGTA $(p<0.01, \mathrm{DN}$ vs DC)

\section{Discussion}

We have established immortalised B lymphoblast cell lines from IDDM patients with and without DN. This experimental approach allows determination of potentially inherited abnormalities of intracellular signal transduction because confounding influences of the hyperglycaemic diabetic in vivo mileu are very unlikely to persist after prolonged cell culture. Subsequently, we quantified the PAF-induced increase in $\left[\mathrm{Ca}^{2+}\right]_{\mathrm{i}}$, which is predominantly mediated via PTXsensitive $G_{i}$-type $G$ proteins in B lymphoblasts [17, 25]. Lymphoblasts from IDDM patients with DN displayed significantly higher increases in $\left[\mathrm{Ca}^{2+}\right]_{i}$ above baseline compared to lymphoblasts from IDDM patients without DN both in the presence and absence of extracellular $\mathrm{Ca}^{2+}$ ions. On the other hand, we found no correlation between the duration of IDDM or donor age and the increase in $\left[\mathrm{Ca}^{2+}\right]_{\mathrm{i}}$ (data not shown and [26]). Agonist-evoked increases in $\left[\mathrm{Ca}^{2+}\right]_{i}$ correlate reasonably well with the activation of $G_{i}$ proteins as inferred from MAS-7 stimulated binding of $\left[{ }^{35} \mathrm{~S}\right] \mathrm{GTP} \gamma \mathrm{S}$ to permeabilised lymphoblasts. The fact that differences in stimulated GTP $\gamma \mathrm{S}$ binding between DN and DC cell lines did not reach statistical significance is mainly due to the restricted number of respective determinations that could be performed under comparable experimental conditions. The

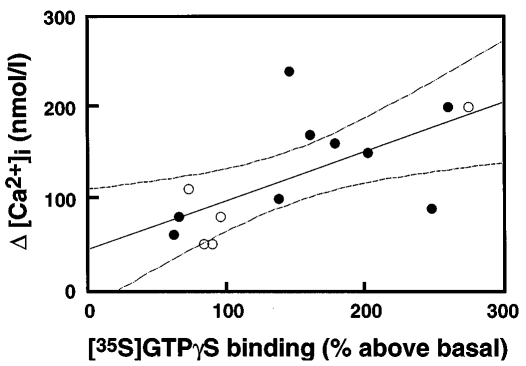

Fig. 3. Correlation between $\mathrm{G}$ protein activation expressed as mastoparan-7 (M-7, $30 \mu \mathrm{mol} / \mathrm{l})$ stimulated binding of $\left[{ }^{35} \mathrm{~S}\right] \mathrm{GTP} \gamma \mathrm{S}$ to permeabilised lymphoblasts and PAF $(0.1 \mu \mathrm{mol} / \mathrm{l})$-induced increase in cytosolic free calcium concentration $\left(\triangle\left[\mathrm{Ca}^{2+}\right]_{\mathrm{i}}\right)$ in lymphoblasts from diabetic patients without $(\bigcirc)$ and with $(\bigcirc)$ diabetic nephropathy $\left(r^{2}=0.42\right.$; $p=0.012)$

enhanced activation of $\mathrm{G}_{\mathrm{i}}$-type $\mathrm{G}$ proteins in $\mathrm{DN}$ is not caused by an overexpression which resembles our previous observation in cell lines from hypertensive subjects [17, 18]. Hence, the molecular reason for this remains to be unravelled.

It should be emphasised that the present study was not intended to be an epidemiological one. Immortalisation and prolonged culture of cell lines from large numbers of IDDM patients is desirable but hardly feasible. A striking similarity exists between the findings reported here and those published previously on immortalised lymphoblasts from IDDM patients with DN and patients with essential hypertension (without IDDM), which in our view, makes the present observations highly plausible: Thus, the phenotype of enhanced $\mathrm{Na}^{+} / \mathrm{H}^{+}$exchanger activity persists in immortalised B lymphoblasts $[16,19]$ and skin fibroblasts $[13,14]$ from $\mathrm{DN}$ patients and patients with hypertension [15] and is tightly linked to an accelerated cell proliferation. Both B lymphoblasts as well as skin fibroblasts from hypertensive patients with enhanced $\mathrm{Na}^{+} / \mathrm{H}^{+}$exchanger activity display a selective enhancement of activation of $\mathrm{G}_{\mathrm{i}}$-type $\mathrm{G}$ proteins $[17,18]$. It is, therefore, not too surprising that the same phenomenon, i.e. increased $G_{i}$ protein activation, is now also described in IDDM patients with DN. Furthermore, the findings presented here are supported by in vivo studies: IDDM patients with DN respond with an increased vasoconstriction to infusion of clonidine, which activates $\alpha_{2}$-adrenoceptors coupled to $G_{i}$ proteins, whereas vasoconstriction in response to the $\alpha_{1}$-adrenoceptor agonist phenylephrine, which activates PTX-insensitive $G$ proteins, is not significantly different in IDDM patients with and without DN [27]. However, the striking similarities in terms of increased cellular signalling in both hypertension and DN may also cause some concern regarding a potential selection bias in this study and those performed by others $[16,19]$. This concern relates to the relative excess of patients with hypertension in the DN group compared to the low number 


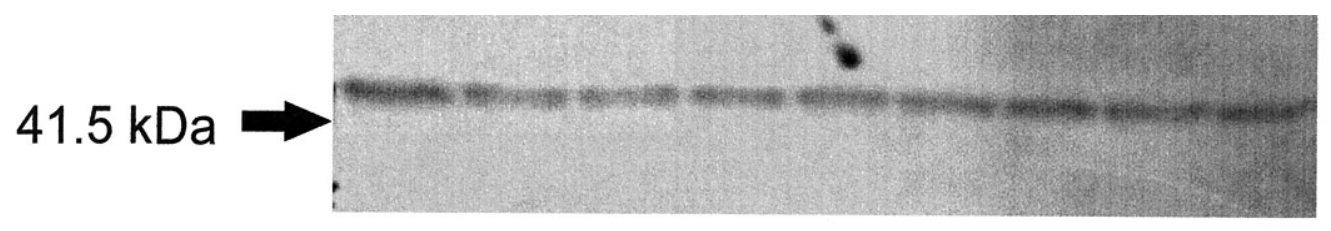

\section{DN DC DN DC DN DC DN DC DN}

Fig. 4. Representative Western blot analysis of G protein subunit expression in lymphoblast membranes from $4 \mathrm{DC}$ and 5 DN patients. Blots were probed with an antibody directed against $\mathrm{G} \alpha_{i, \text { common }}$

of hypertensive individuals in the DC group both in the present as well as in previous studies $[16,19]$. It is, therefore, at present difficult to decide, whether abnormal cellular signal transduction is a typical feature and a potential pathogenetic mechanism for DN or just a reflection of the large number of hypertensive individuals who unavoidably accumulate among IDDM patients with DN. On the other hand, an enhanced activation of $G_{i}$ proteins could represent the cellular substrate of a common genetic predisposition for both hypertension and, in the hyperglycaemic condition of IDDM, the development of DN.

Based on our findings, we should like to propose an alternative hypothesis regarding the pathogenesis of nephropathy in IDDM. High extracellular glucose concentration induces an increased de novo synthesis of diacylglycerol (DAG) in the kidney [28] which in turn activates protein kinase $\mathrm{C}$ and phospholipase $A_{2}[29,30]$. This results in the synthesis and release of multiple autocrine and paracrine growth factors as well as lipid mediators involved in the pathogenesis of diabetic nephropathy from early changes to the late stage of irreversible kidney damage.

Glomerular hyperfiltration is the first functional alteration during the early stage of the disease. Alterations in mesangial contractility, which can be caused by the action of PAF and lysophosphatidic acid [31, 32] and an enhanced vasoconstrictor effect of angiotensin II on the vas efferens have been proposed among others [33]. These actions of PAF, lysophosphatidic acid and angiotensin II [34] are largely mediated by PTX-sensitive G proteins in the kidney. Angiotensin II not only stimulates phospholipase $\mathrm{C}$ and $\mathrm{A}_{2}$, which results in the release of arachidonic acid and an increase in prostaglandin $\mathrm{E}_{2}$ [35], but also stimulates extracellular matrix protein synthesis and cellular hypertrophy in glomerular mesangial and proximal tubular cells by the autocrine induction of transforming growth factor $\beta$ (TGF- $\beta$ ) and plateletderived growth factor (PDGF) [36--38]. PDGF and TGF- $\beta$ seem to be directly involved in the initiation of cellular hypertrophy, matrix and collagen expres- sion, and glomerulosclerosis. The cellular actions of PDGF are partially mediated by PTX-sensitive G proteins [39, observations from our laboratory].

The above-described mechanisms induced through elevated glucose concentrations are already detrimental in IDDM patients with "normal" " activation of PTX-sensitive G proteins. Patients with enhanced activation of PTX-sensitive G proteins, however, would experience a much more vigorous cellular activation by the above-mentioned compounds. Thus, typical diabetic complications such as DN may develop much earlier and/or be more pronounced during the natural course of IDDM.

In summary, our data apparently support the hypothesis of an inherited predisposition to $\mathrm{DN}$ in IDDM patients. This may be due to an increased activation of PTX-sensitive $G$ proteins, which are key mediators in pathogenic processes of this major complication of IDDM. So far, the enhanced activation of $\mathrm{G}_{\mathrm{i}}$ proteins may serve as an intermediate phenotype for IDDM patients at risk for developing diabetic nephropathy, until a true genetic marker has been identified.

Acknowledgements. This study was supported by a grant from the IFORES program of the medical faculty of the University Hospital Essen.

\section{References}

1. United States Renal Data System 1996 Annual Data Report (1996) II: Incidence and prevalence of ESRD. Am J Kidney Dis 28 [Suppl 2]:S34--S47

2. Selby JV, FritzSimmons SC, Newman JM et al. (1990) The natural history and epidemiology of diabetic nephropathy. JAMA 263: 1954--1960

3. Rossing P, Rossing K, Jacobson P, Parving H-H (1995) Unchanged incidence of diabetic nephropathy in IDDM patients. Diabetes 44: 739--743

4. Parving H-H, Østerby R, Anderson PW, Hsueh WA (1995) Diabetic nephropathy. In: Brenner BM (eds) The kidney, vol 2. Saunders, Philadelphia, pp 1864--1892

5. Borch-Johnsen K, Nørgaard K, Hommel E et al. (1992) Is diabetic nephropathy an inherited complication? Kidney Int 41: 719--722

6. Seaquist ER, Goetz FC, Rich S, Barbosa J (1989) Familial clustering of diabetic kidney disease. N Engl J Med 320: 1161--1165

7. Barzilay J, Warram JH, Bak M et al. (1992) Predisposition to hypertension: risk factor for nephropathy and hypertension in IDDM. Kidney Int 41: 723--730 
8. Earle K, Walker J, Hill C, Viberti GC (1992) Familial clustering of cardiovascular disease in patients with insulin-dependent diabetes and nephropathy. N Engl J Med 326: 673--677

9. Krolewski AS, Canessa M, Warram JH et al. (1988) Predisposition to hypertension and susceptibility to renal disease in insulin-dependent diabetes mellitus. N Engl J Med 318: 140--145

10. Mangili R, Bending JJ, Scott G et al. (1988) Increased sodium-lithium countertransport activity in red cells of patients with insulin-dependent diabetes mellitus and nephropathy. N Engl J Med 318: 146--150

11. Trevisan R, Viberti G (1995) Genetic factors in the development of diabetic nephropathy. J Lab Clin Med 126: 342--349

12. Busch S, Burckhardt B-C, Siffert W (1995) Expression of the human sodium-proton exchanger NHE-1 in Xenopus laevis oocytes enhances sodium-proton exchange activity and establishes sodium-lithium countertransport. Pflügers Arch 429: 859--869

13. Davies JE, Ng LL, Kofoed-Enevoldson A et al. (1992) Intracellular $\mathrm{pH}$ and $\mathrm{Na}^{+} / \mathrm{H}^{+}$antiport activity of cultured skin fibroblasts from diabetics. Kidney Int 42: 1184--1190

14. Trevisan R, Li LK, Messent J et al. (1992) $\mathrm{Na}^{+} / \mathrm{H}^{+}$antiport activity and cell growth in cultured skin fibroblasts of IDDM patients with nephropathy. Diabetes 41: 1239--1246

15. Rosskopf D, Frömter E, Siffert W (1993) Hypertensive sodium-proton exchanger phenotype persists in immortalized lymphoblasts from essential hypertensive patients: a cell culture model for human hypertension. J Clin Invest 92: 2553--2559

16. Ng LL, Davies JE, Siczkowski M et al. (1994) Abnormal $\mathrm{Na}^{+} / \mathrm{H}^{+}$antiporter phenotype and turnover of immortalized lymphoblasts from type 1 diabetic patients with nephropathy. J Clin Invest 93: 2750--2757

17. Siffert W, Rosskopf D, Moritz A et al. (1995) Enhanced G protein activation in immortalized lymphoblasts from patients with essential hypertension. J Clin Invest 96: 759--766

18. Pietruck F, Moritz A, Montemurro M et al. (1996) Selectively enhanced cellular signaling by $\mathrm{G}_{i}$ proteins in essential hypertension. $\mathrm{G} \alpha_{\mathrm{i} 2}, \mathrm{G} \alpha_{\mathrm{i} 3}, \mathrm{G} \beta_{1}$, and $\mathrm{G} \beta_{2}$ are not mutated. Circ Res 79: 974--983

19. Sweeney FP, Siczkowski M, Davies JE et al. (1995) Phosphorylation and activity of $\mathrm{Na}^{+} / \mathrm{H}^{+}$exchanger isoform 1 of immortalized lymphoblasts in diabetic nephropathy. Diabetes 44: 1180--1185

20. Grynkiewicz G, Poenie M, Tsien RY (1985) A new generation of $\mathrm{Ca}^{2+}$ indicators with greatly improved fluorescence properties. J Biol Chem 260: 3440--3450

21. Wieland T, Liedel K, Kaldenberg-Stasch S et al. (1995) Analysis of receptor- $\mathrm{G}$ protein interactions in permeabilited cells. Naunyn-Schmiedeberg's Arch Pharmacol 351: 329--336

22. Bradford MM (1976) A rapid and sensitve method for quantitation of microgram quantities of protein utilizing the principle of protein-dye binding. Anal Biochem 72: $248--254$

23. Laemmli UK (1970) Cleavage of structural proteins during the assembly of the head of bacteriophage $T_{4}$. Nature (Lond) 227: 680--685
24. Ross EM, Higashijima T (1994) Regulation of G-protein activation by mastoparan and other cationic peptides. Methods Enzymol 237: 27--38

25. Mazer BD, Sawami H, Tordai A, Gelfand AW (1992) Platelet-activating factor-mediated transmembrane signaling in human B lmphocytes is regulated through a pertussis- and cholera toxin-sensitive pathway. J Clin Invest 90: 759--765

26. Gruska S, Ihrke R, Stolper S, Kraatz G, Siffert W (1997) Prevalence of increased intracellular signal transduction in immortalized lymphoblasts from patients with essential hypertension and normotensive subjects. J Hypertens 15: 29-33

27. Bodmer CW, Schaper NC, Janssen M, De Leeuw PW, Williams G (1995) Selective enhancement of alpha 2-adrenoceptor-mediated vasoconstriction in insulin-dependent diabetic patients with microalbuminuria. Clin Sci 88: 421--426

28. Craven PA, Patterson MC, DeRubertis FR (1990) Increase in diacylglycerol mass in isolated glomeruli by glucose from de novo synthesis of glycerolipids. Diabetes 39: 667--674

29. Williams B, Schrier RW (1993) Glucose-induced protein kinase $\mathrm{C}$ activity regulates arachidonic acid release and eicosanoid production by cultured glomerular mesangial cells. J Clin Invest 92: 2889--2896

30. Choi K (1995) Effect of high glucose concentration on phospholipase A2 activity in mesangial cells. Kidney Int 48:S-22--S-27

31. Schlondorff D, Neuwirth R (1986) Platelet-activating factor and the kidney. Am J Physiol 251 (Renal Fluid Electrolyte Physiol 20):F1--F11

32. Inoue CN, Forster HG, Epstein M (1995) Effects of lysophosphatidic acid, a novel lipid mediator, on cytosolic $\mathrm{Ca}^{2+}$ and contractility in cultured rat mesangial cells. Circ Res 77: 888--896

33. Larkins RG, Dunlop ME (1992) The link between hyperglycemia and diabetic nephropathy. Diabetologia 35: 499-504

34. Douglas JG, Hopfer U (1994) Novel aspect of angiotensin receptors and signal transduction in the kidney. Annu Rev Physiol 56: 649--669

35. Schlondorff D, DeCandido S, Satriano JA (1987) Angiotensin II stimulates phospholipases $\mathrm{C}$ and $\mathrm{A}_{2}$ in cultured rat mesangial cells. Am J Physiol 253 (Cell Physiol 22):C113--C120

36. Kagami S, Border WA, Noble NA (1994) Angiotensin II stimulates extracellular matrix protein synthesis through induction of transforming growth factor- $\beta$ expression in rat glomerular mesangial cells. J Clin Invest 93: 2431--2437

37. Wolf G, Mueller E, Stahl RAK, Ziyadeh FN (1993) Angiotensin II-induced hypertrophy of cultured proximal tubular cells is mediated by endogenous transforming growth factor- $\beta$. J Clin Invest 92: 1366--1372

38. Tanaka R, Sugihara K, Tatematsu A, Fogo A (1995) Internephron heterogeneity of growth factors and sclerosis -Modulation of platelet-derived growth factor by angiotensin II. Kidney Int 47: 131--139

39. Zhang LM, Newman WH, Castresana MR, Hildebrandt JD (1994) The effect of pertussis toxin on the growth of vascular smooth muscle cells stimulated by serum or platelet-derived growth factor. Endocrinology 134: 1297--1304 